\title{
An Urethral Stone Mimicking Urinary Tract Infection in a Twenty-six-month-old Boy
}

\section{Yirmi Altı Aylk Erkek Çocukta Üriner Enfeksiyonu Taklit Eden Üretra Taşı}

\author{
Mehmet Giray Sönmez, Cengiz Kara \\ Medical Park Hospital, Clinic of Urology, Ankara, Turkey
}

\begin{abstract}
A 26-month-old boy, who was misdiagnosed with urinary tract infection, was admitted to our hospital with increasing complaints of uneasiness, vomiting and nausea. On physical examination, a urethral stone was suspected and was confirmed by plain urinary tract $x$-ray. In children, the clinical features of a urethral stone may be overlooked because children are not able to express their complaints fully. Therefore, a detailed and careful physical examination is of great importance. In this paper, we present the rare case of urethral stone in a child and a review of the literature.
\end{abstract}

Keywords

Urinary infection, urethral stone, phimosis, lithotripsy

\section{ÖZ}

Burada sunduğumuz 26 aylık erkek çocuk hasta daha önce üriner enfeksiyon tanısıyla tedavi almış ancak rahatlamamıştır. Huzursuzluk, bulantı, kusma şikayetlerindeki artış üzerine kliniğimize başvuran hastaya yapılan fizik muayenede üretra taşından şüphelenilerek, çekilen direk üriner sistem grafisi ile tanı kesinleştirilmiş̧ir. Özellikle çocuk yaş grubu hastalarda görülen üretra taşlarında yakınmalar tam olarak dile getirilemediği için klinik maskelenebilir. Bu nedenle dikkatli olunmalı ve fizik muayeneye özen gösterilmelidir. Buradaki olgu sunumumuzda nadir görülen bu olgu ile birlikte mevcut literatürü incelemeyi amaçladık.

\section{Anahtar Kelimeler}

Üriner enfeksiyon, üretra taşı, fimozis, litotripsi

\section{Introduction}

Urethral stones are a rare condition usually observed more frequently in the male population. Urethral calculi account for less than 1\% of all urinary tract stone disease. They can be classified as primary or autochthonous that are formed de novo in the urethra, and secondary or migrating that are formed in the upper urinary system with secondary downward descent.

A 26-month-old boy, who was misdiagnosed with urinary tract infection, was admitted to our hospital with increasing complaints of uneasiness, vomiting and nausea. Following the physical examination the presence of a urethral stone was confirmed by plain urinary tract $x$-ray. The patient was discharged on the next day in perfect health after receiving a distal urethra stone treatment via endoscopy. In children, the clinical features of a urethral stone may be overlooked because children are not able to express their complaints fully. Therefore, a detailed and careful physical examination is of great importance. In this paper, we present the rare case of urethral stone in a child and a review of the literature.

\section{Case Presentation}

A 26-month-old boy was brought to a pediatrician with the complaints of restlessness, nausea, vomiting, and insomnia for the past three weeks. No pathologies were detected on the abdominal ultrasonography and antibiotic treatment was given considering urinary system infection after the detection of high amount of erythrocyte and leukocyte in the complete urine analysis, but the complaints continued. After stomachache, penile pain, crying when urinating and restlessness were added to the present complaints, he was evaluated by an urologist and pediatrician in a different center. Considering that the complaints were due to phimosis-related urinary infection, circumcision was recommended after antibiotic treatment. Since the complaints did not improve, the patient was referred to our clinic.

On physical examination, phimosis was present and a hard mass measuring approximately $1 \times 1 \mathrm{~cm}$ in size was palpated in the fossa navicularis compatible with stone.

Laboratory evaluation revealed normal urea and creatinine levels, white blood cell count of 10100, and hemoglobin of 12.7 as well as high amount of erythrocytes in the urine. 
Radiological evaluation of the urinary tract revealed an almost 9.5 $\mathrm{mm}$ long opacity in the distal part of the penis, compatible with stone (Figure 1).

A urethral stone measuring $9.5 \mathrm{~mm}$ in diameter was observed in the fossa navicularis with the use of $8 \mathrm{~F}$ pediatric cystoscopy under general anesthesia. After that, the stone was broken using a pneumatic lithotripter (Figure 2). Stone pieces were completely removed using a stone holder. The patient, who also had phimosis, was circumcised surgically. The operation was ended after placement of an 8F Foley catheter. The patient was discharged following catheter removal a day after the operation. Stone analysis of the patient whose complaints were relieved after the operation Fourier transform infrared spectroscopy was reported as calcium oxalate stone.

\section{Discussion}

Urethral stones are rare pathologies observed more commonly in men (1). While most of the urinary stones are seen in the upper urinary

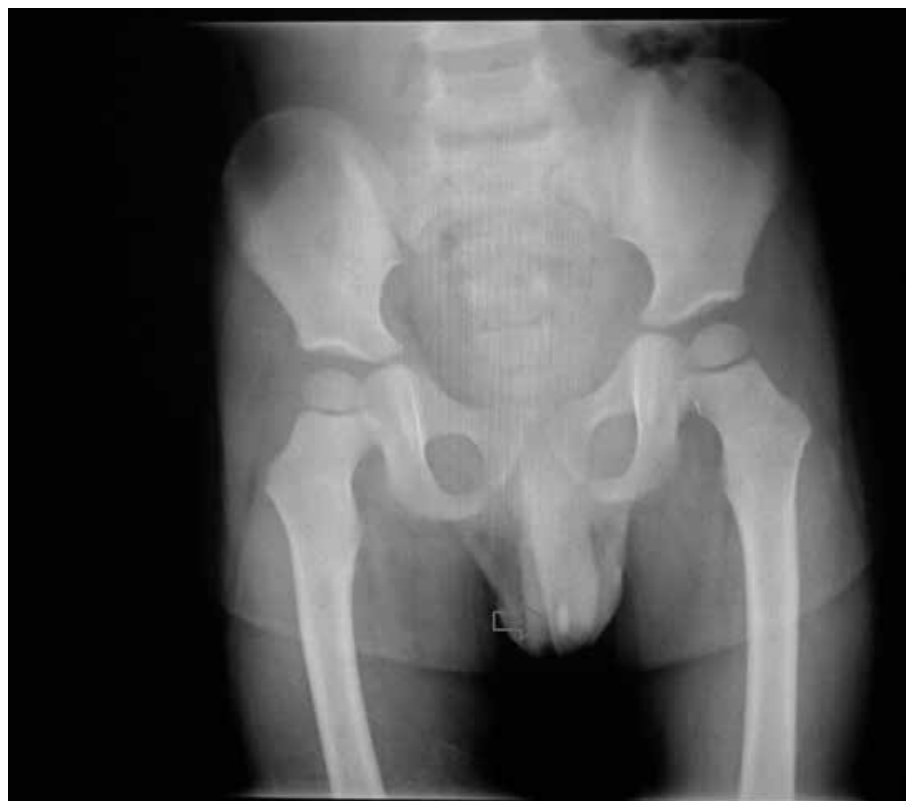

Figure 1. Plain urinary tract $\mathrm{x}$-ray image showing a stone located in the distal urethra

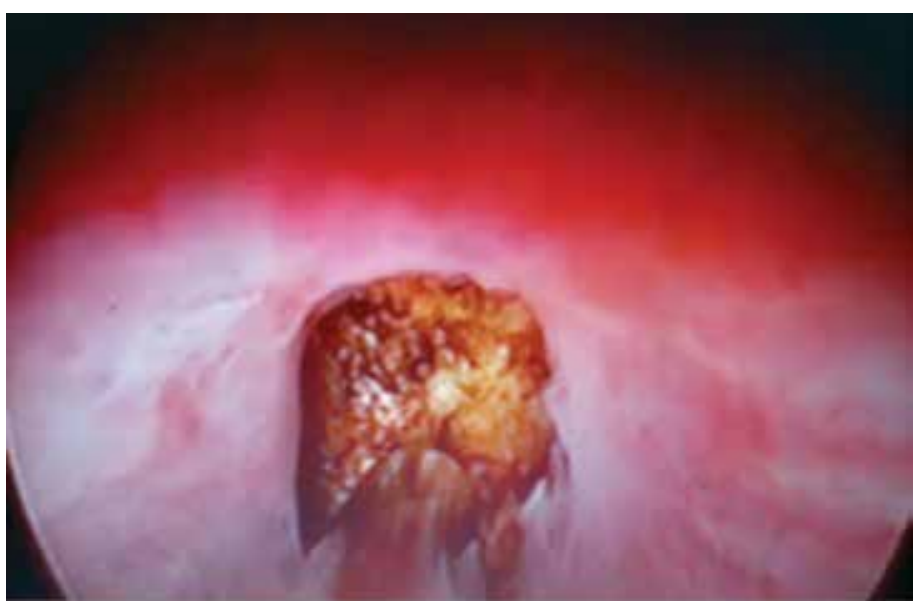

Figure 2. Breaking the stone impacted in the urethra using a pneumatic lithotripter tract and the bladder, nearly $1 \%$ of all calculi are seen in the urethra (2). Urethral stones can be classified as primary or autochthonous that are formed de novo in the urethra, and secondary or migrating that are formed in the upper urinary system with secondary downward descent. Primary urethral stones are associated with urethral abnormalities such as stricture and diverticule (3). Treatment options for urethral stones vary according to the location and size of the stone as well as associated urethral disease (4). Urethral stones are generally seen as single stone. They are more frequently seen in males than in females, attributable to the fact that bladder stones are less frequently observed in women and women have a shorter urethra (5). Urethral stones can be seen in any site along the urethra, from posterior urethra up to external meatus. Most of the urethral stones are found in the posterior urethra (6). However, in their series including 19 pediatric patients with urethral stones, Akhtar et al. (7) have reported that the stones were found in the anterior urethra in $63.1 \%$ of patients (12 patients). Urethral stones are more frequently observed in children than in adults (6). In our case, in line with the literature, just one stone migrated from the upper urinary system and caused anterior urethral obstruction in a 26-month-old male patient.

General complaints of patients with urethral stone include burning sensation and frequent urination, bleeding during urination, urinary retention, urinary incontinence, and scrotal or perineal pain. The findings may include a palpable urethral stone, urinary infection and detection of kidney failure if ignored $(8,9)$. The misdiagnosis of urinary infection was made in other centers due to the inability of our patient to completely express his complaints since he was too young, as well as the presence of restlessness and crying when urinating and accompanying nausea and vomiting and, treatment was provided but the patient was not relieved. A detailed and careful physical examination in patients with suspected urethral stones, especially in pediatric patients, who have these complaints and do respond to antibiotic treatment, is of great importance.

Presence of palpable stones as in our case is satisfactory for diagnosis most of the time. However, especially posterior urethral stones may not be palpable. Therefore, x-rays represent the first option for diagnosis. Roentgenography should include especially the pubic area and its inferior. Plain $\mathrm{x}$-rays also demonstrate opaque stones. As the second choice, ultrasonography is valuable especially in the evaluation of the upper urinary system and posterior urethral stones. In patients in whom the diagnosis cannot be established, retrograde urethrography, computed tomography and penile ultrasonography are radiological methods helping diagnosis. The final diagnosis can be made using endoscopy $(9,10)$.

The treatment of urethral stones varies according to the size, shape, localization and movement of the stone and urethral condition (11). Lithotripsy and removal of stone fragments with ureteroscopic pneumatic or holmium laser can be used in every condition. If the stone is in the fossa navicularis or external meatus, milking or meatotomy can be done. If the stone is in the anterior urethra, it can be extirpated using a stone holder. If the narrowness in the urethra has prevented the passage of the stone, urethral dilatation and internal urethrotomy may be necessary. External urethrotomy may be necessary in chronic, impacted urethral stones. Bladder stones may be treated by pushing the stones in the posterior urethra towards the bladder. If the stone was formed in diverticulum, diverticulectomy should be done $(10,11)$. Since the stone was too big to deliver or extirpate with a holder in 
our case, pneumatic lithotripsy was made. Considering postoperative condition of the urethra, it may be necessary to locate a urethral catheter or suprapubic catheter (11).

For stones that are small and not impacted or not causing a severe mucosal damage, endoscopic treatment choices decrease the hospitalization period and treatment cost $(9,10,11)$. In this case, the urethral stone was removed by pneumatic lithotripsy using a pediatric cystoscope and, then, the child who had phimosis was surgically circumcised. At the end of the operation, an 8F Foley catheter was placed and it was taken out on the first day after the operation and clinically healthy patient was discharged.

In conclusion urethral stones may imitate urinary infection in children. It may be clinically masked since the complaints cannot be expressed completely by pediatric patients. In this age group, the complaints can be associated with phimosis. Therefore, a careful and detailed physical examination should be performed and urethral stones should be considered. Preferring endoscopic treatment methods in the treatment of these patients reduces the need for catheterization, length of hospital stay and treatment cost.

\section{Authorship Contributions}

Informed Consent: Consent form was filled out by all participants, Concept: Mehmet Giray Sönmez, Cengiz Kara, Design: Mehmet Giray Sönmez, Cengiz Kara, Data Collection or Processing: Mehmet Giray Sönmez, Cengiz Kara, Analysis or Interpretation: Mehmet Giray Sönmez, Literature Search: The literature search was done with pubmed, Writing: Mehmet Giray Sönmez, Peer-review: Internal peerreviewed, Conflict of Interest: No conflict of interest was declared by the authors, Financial Disclosure: The authors declared that this study has received no financial support.

\section{References}

1. Gali BM, Ali N, Agbese G0, Garba II, Musa K. Urethral calculi in youngadult Nigerian males: a case series. West Afr J Med 2011;30:457-460.

2. Shanmugam TV, Dhanapal $V$, Rajaraman $T$, Chandrasekar CPM, Balashanmugam KP. Giant urethral calculi. Hosp Med 2000;61:582.

3. Ahmed OV, Akhtar M, Gulfam, Din G. Giant urethral diverticulum with calculi. Pak J Surg 2003;19:106-108.

4. Ho-KLV, Segura JW. Lower urinary tract calculi. In: Wein AJ, Kavoussi LR, Novick AC, Partin AW, Peters CA. Campbell-Walsh Urology, 9th ed. Philadelphia, Elsevier\&tSaunders, 2007, pp 2670-2672.

5. Suzuki $Y$, Ishigooka M, Hayami S, Nakada T, Mitobe K. A case of primary giant calculus in female urethra. Int Urol Nephrol 1997;29:237-239.

6. Verit $A$, Savas $M$, Ciftci $H$, Unal $D$, Yeni $E$, Kaya M. Outcomes of urethral calculi patients in an endemic region and an undiagnosed primary fossa navicularis calculus. Urol Res 2006;34:37-40.

7. Akhtar J, Ahmed S, Zamir N. Management of impacted urethral stones in children. J Coll Pysicians Surg Pak 2012;22:510-513.

8. Hegele $A$, Olbert $P$, Wille $S$, Heidenreich $A$, Hofmann R. Giant calculus of the posterior urethra following recurrent penile urethral stricture. Urol Int 2002;69:160-161.

9. Kilciler M, Erdemir F, Bedir S, Çoban S, Erten K, Özgök Y. Kliniğimizdeki üretral taşlı olguların literatür eşliğinde değerlendirilmesi. Turk Urol Derg 2005;31:389-395.

10. Görgel SN, Şefik E, Ergin O, Balcı U, Girgin C, Dinçel Ç. Dev Üretra Taşı. Yeni Üroloji Derg 2011;6:46-50.

11. Karataş ÖF, Bayrak Ö, Çimentepe $E_{1}$ Ünal D. Posterior urethral calculi in patients without anatomical abnormalities: Case report. BTDMJB 2008;4:84-86. 